\title{
Visualization Technology in Museum (From the Experience of SibFU Collaboration with the Museums of Russia)
}

\author{
Marina A. Lapteva and Nikita O. Pikov* \\ Siberian Federal University \\ 79 Svobodny, Krasnoyarsk, 660041, Russia
}

Received 12.04.2016, received in revised form 24.05.2016, accepted 20.06.2016

\begin{abstract}
The article represents the experience of the students of Institute for the Humanities of Siberian Federal University work with the leading Russian museums the State Russian Museum and the State Hermitage Museum. The results of the use of modern information technologies in museums that make visiting them interesting and productive for the audience, and a museum a contemporary modern social institution, preserving and representing cultural heritage in interactive contexts are demonstrated.
\end{abstract}

Keywords: museum, information technologies, photography, gigapanoramic shooting, spherical panorama, interactivity, augmented reality, virtualization, the State Russian Museum, the State Hermitage Museum.

DOI: 10.17516/1997-1370-2016-9-7-1674-1681.

Research area: culture studies.

The future of museums in the digital age is definitely connected with the development of information technologies. Their use in the museum can be seen as one of the forms of communication with the visitor. Most museums try to take advantage of new technologies through their "incorporation" into the museum exposition, thus allowing the visitor to get more information, or use the Internet for a more complete picture of the museum collections and activities (virtual representation in the network, virtual museum). If the first way gives possibility to get the visitors interested, the second one greatly extends the museum's audience, making the museum collections accessible. In the professional museum environment views on the more active use of digital technologies are divided. Some believe that their expansion inevitably leads to the transformation of museums into entertainment centers, which threatens to decrease the level of the museum visitors and the loss of a sense of the original, while others see this as an opportunity to attract and keep the visitor, to make a museum open to all who wish to see its collections. Without disputing the value of the original, which is the basis of the traditional museum, the role of information technology as a means of preservation (in the digital form) and the promotion of cultural heritage, as well as providing quality materials

(C) Siberian Federal University. All rights reserved

* Corresponding author E-mail address: krasmargo@mail.ru 
for work to professionals in different countries should not be underestimated.

Despite the challenge of the funds digitization set to museums, the resources of the museum itself, as a rule, are not enough. For example, digitalizing the collection of the Smithsonian Institution, processing one image during a minute, will take 260 years. Therefore, firstly, it is necessary to set clear priorities (paying attention to the items that can be lost or destroyed), and secondly, to attract external assistance, not only in the form of financial investments, which flow can be difficult to predict, but in the form of building partnership relations with universities, where specialists of this profile are educated.

Chair of Information Technology in Creative and Cultural Industries of Institute for the Humanities of Siberian Federal University, which has been collaborating with the leading Russian museums since 2009 can be an example of openness for creative interaction. The importance of this kind of union is that students and lecturers are involved into the solution of specific practical problems connected with the use of digital technologies in the museum environment. Presence of the necessary equipment in the humanitarian informatics laboratory gives possibility to solve many problems, both specific and complex.

Having quite a successful experience in digitizing museums' collections in the city of Krasnoyarsk and presenting them on the Internet, we decided to offer our services to the Russian Museum and then the Hermitage that has the richest collections and the experience of their translation. After receiving the museums consent, the students held their summer internship at the museums of St. Petersburg, appreciating the opportunity to work with the unique material.

The period from 2010 to 2012 is the time of active works on digitalization the collections of the State Russian Museum. It was built on the basis of photofixation technology (which, in fact, is not something new) and gigapanoramic shooting, similar to that which is used in a well-known project Google Art Project (https://www/google.com/ culturalinstitute/project/art-project?hl=ru). The employees of the museum selected the paintings, the possibility of the detailed consideration and study of which for whatever reasons (use in educational programmes, presentation of the Internet, research activity) was important. A number of famous paintings, such as "Capture of the Snow Town" and "The Conquest of Siberia by Yermak" by Vasily Surikov, "Parade Celebrating the End of Military Action in the Kingdom of Poland on 6 October 1831 on Tsaritsyn Lug in Saint Petersburg" by Grigory Chernetsov, "The Ship Grove" by Ivan Shishkin, "The Ninth Wave" by Ivan Aivazovsky, "ANT-20 Maxim Gorky" by Vasily Kuptsov, "Noon" by Kuzma Petrov-Vodkin and "The Walk" by Marc Chagall were digitized with the use of the robotic tripod produced by company GigaPan (the development of the scientists from Carnegie Mellon University) for digital camera that gives possibility to take gigapixel images with the resolution of more than one billion pixels. The digital camera is adjusted to a special robotic tripod attachment. The robot tripod takes a certain number of shots in few minutes and GigaPan Stitcher application installed on the computer stitches them into one. In such a picture you can see even the smallest details. The history of work with the picture of Russian artist Grigory Chernetsov, which depicts a parade on the occasion of the suppression of the Polish uprising of 1830 1831, is of particular interest. It is the most famous painting of the artist, which is quite a valuable iconographic document: about 300 well-known people of the time are depicted in it, representing all the social classes of Russia (writers, artists, scientists, military men and the imperial family). Due to the fact that the painting was dedicated to the important event for 


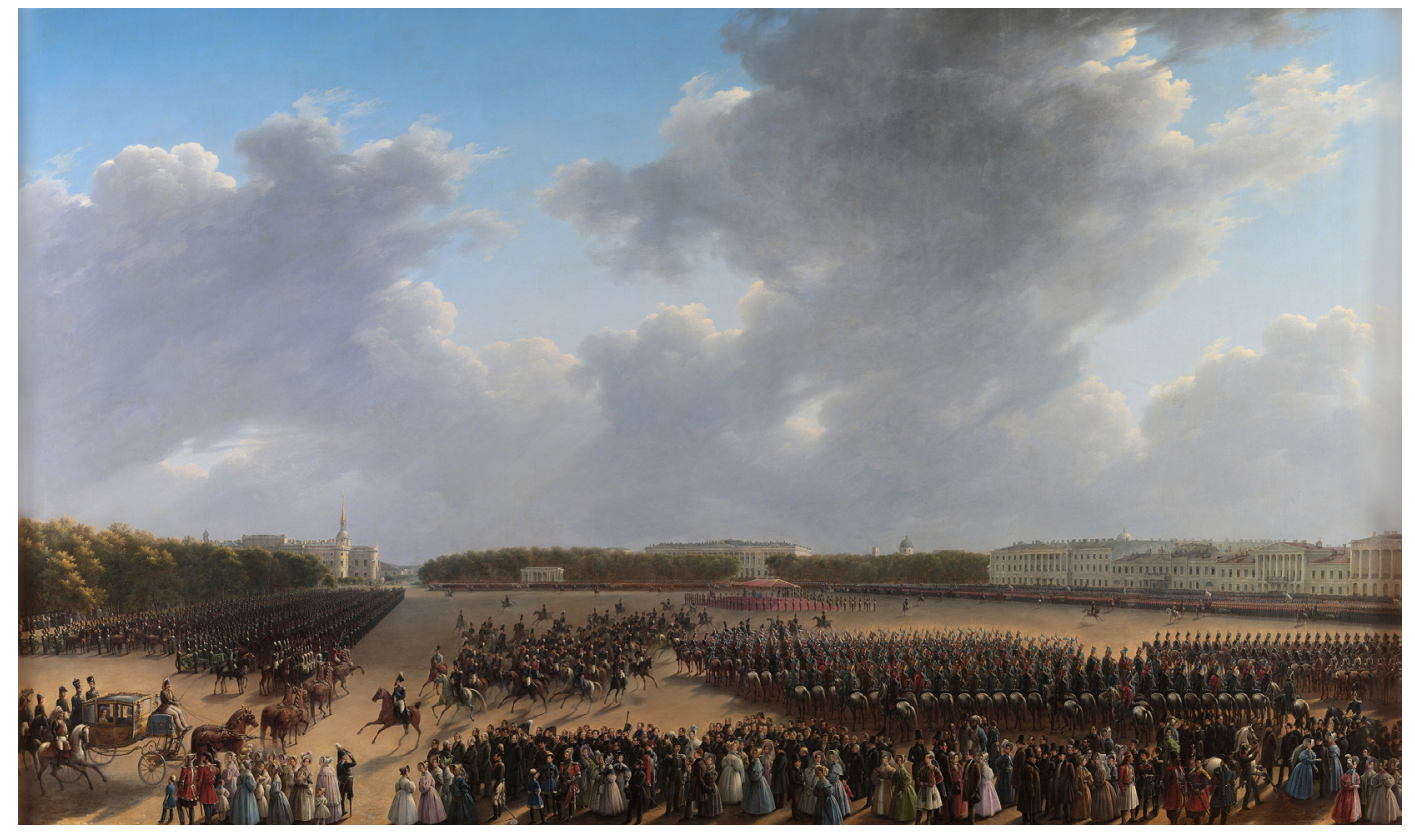

G.G. Chernetsov "Parade on Tsaritsyn Lug on 6 October 1831”. The State Russian Museum

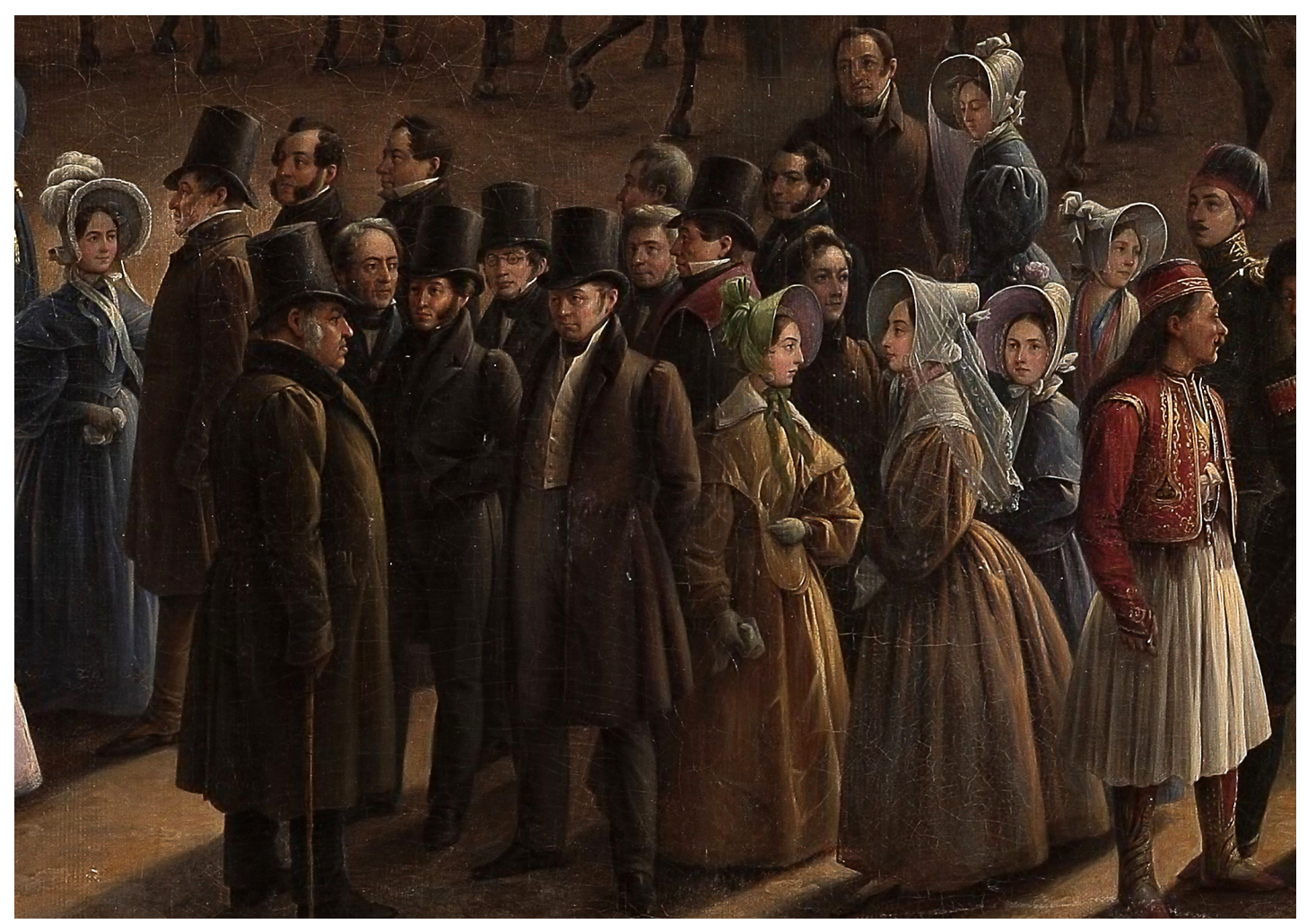

Enlarged fragment of the painting by G.G. Chernetsov "Parade on Tsaritsyn Lug on 6 October 1831" The State Russian Museum 
Russia, the list of its characters was approved by Nicholas 1 , who was under a great impression of the paintings by the German artist Franz Krüger "Parade on the Opernplatz in Berlin". It was planned to place Chernetsov's painting in the Winter Palace. Critics pointed out its historical significance: each character, as it has already been mentioned, had to be approved by the emperor and departments entrusted by him, and it spoke about what people and events were considered significant for Russia of the 1830s. Thus, the students and lecturers' work made it possible to study the painting of the artist in detail both to the viewer, and the researcher. With the consent of the State Russian Museum the painting by Grigory Chernetsov was published on the imagehosting site GigaPan.com (http://www.gigapan. com/gigapans/87249). Later the digitized copy was used in the projects implemented by the State Russian Museums such as "The Russian Museum. Augmented Reality." and "The State Russian Museum. Chernetsov. Parade".

Many scholars representing various fields of scientific knowledge actively use GigaPan as a tool. For example, Sandra Olsen, the rock painting specialist, uses this technology in the study of ancient petroglyphs in Saudi Arabia. Sometimes it turns out to be more effective than working with the exhibit itself: it is possible to study the hard to reach places in detail.

At the same period, spherical panoramas shooting of the interiors and exteriors of the State Russian Museum, the Field of Mars, the Summer Garden after the reconstruction and M. Nesterov's exhibition (more than 200 spherical panoramas) was made. It was planned to use the results in the process of creating electronic catalogues of the Russian Museum on CDs and virtual tours. At the heart of spherical panorama is the image taken from a large number of shots, the angle of the shoot space is maximum $(180 \times 360$ degrees). These panoramas are demonstrated by visualization based on flash technology, Java Script, etc. The ability to control the direction of view, zoom in or delete the image allows the viewer to focus on the details of interests.

At AAIT conference in Khanty-Mansiysk, the acquaintance with the staff of the State Hermitage, who appreciated the work of our students and with whom we share common interests, took place. Thus, since 2013 the Chair has been cooperating with the archaeological department of the State Hermitage. The work, primarily, was connected with digital preservation of archaeological artifacts in ultrahigh resolution. During this time, gigapanoramic shooting of the slabs with the petroglyphs of Lake Onega, the individual objects in the class "The Past at Your Fingertips", panoramic shooting of the permanent exhibitions of the Department of Eastern European and Siberian Archeology (DEESA), exhibition "Bronze Age. Europe Without Borders" in the Headquarters, the Large Carriage House, attics and cellars of the Winter Palace, Kutuzov Corridor, Restoration and Storage Centre "Staraya Derevnya", boilers of the building of Stock Exchange on the Spit of Vasilevsky Island, the European Biennial of Contemporary Art "Manifesto 10", as well as shooting of the interiors in the Small Hermitage and the Grand Church of the Winter Palace was carried out. Videos were prepared interviews with the custodians for information support of the exhibition ("Perm Animal Style", etc.). The possibility of studying petroglyphs with the help of gigapanoramic shooting has been mentioned above. Attics and basements of the Hermitage are not public places, not only for the visitors, but for the museum staff as well. It is unlikely that anyone interested will be able to see them without special permission. Now such hope has appeared. In the department of archeology they had a chance to work with each exhibit. In the exhibition such an exhibit may get lost in the 


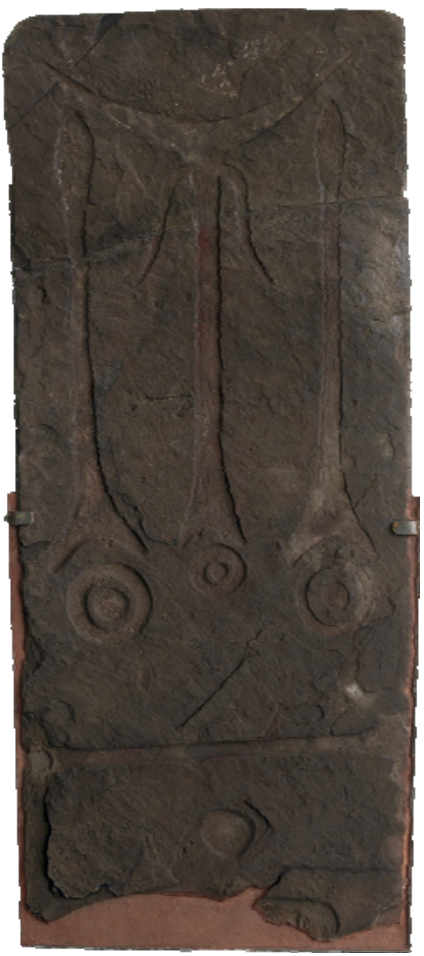

Petroglyphs. "Okunev Culture”. The State Hermitage

mass of the similar others. In order it could start "performing", be able to tell about itself, different scenarios for its presentation with the use of multimedia technologies came up. Story lines that created a specific context, making the perception of a museum object meaningful, emotional and interesting were developed in the experiment format. Such presentation of the material is a kind of cultural provocation, but in a good sense of the word: it is important to arouse the interest of the audience, especially the young that live in the age of visual presentation of information.

In the process of capturing images in non-studio environment where every time it is necessary to adapt to a particular situation, glarefree method of shooting, tested on in the paintings of the Krasnoyarsk Art Museum named after V.I. Surikov and successfully applied to the collections of the Russian Museum, was developed.

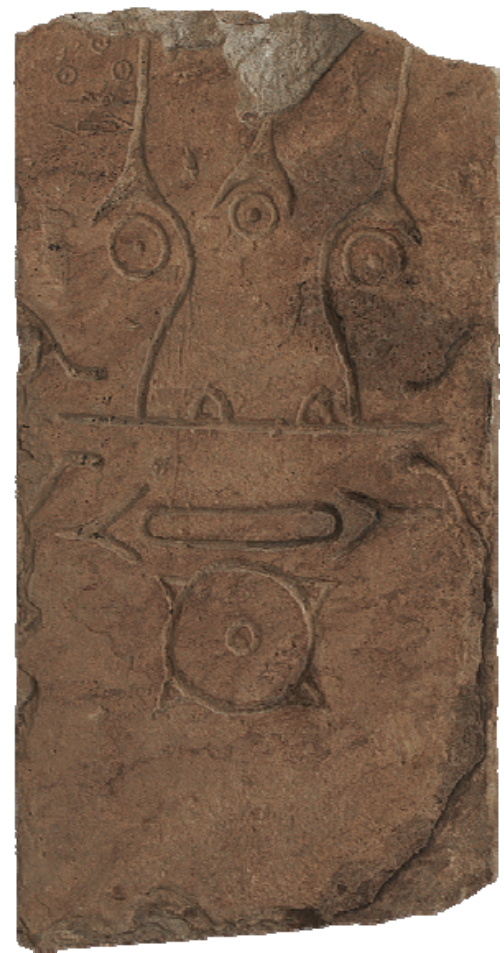

Augmented reality is a new interactive technology for the museum that allows augmenting the perception of real exhibitions in the museum with the context information in the form of articles, links, videos and images. A mobile device camera is pointed at an object and the information as indicated above is displayed on the screen. The advantages of using augmented reality in the museum are obvious: it is possible to get detailed information about a museum object very quickly and its functioning can be clearly illustrated, to see the accessories that are not on display in the exhibition, for whatever reason, but are kept in the museum funds (possibly of another museum), nonexistent objects can be superimposed on a real space creating the effect of presence, it is possible to observe an object in its natural environment, interactive exhibitions with the use of augmented reality technology, as a rule, 


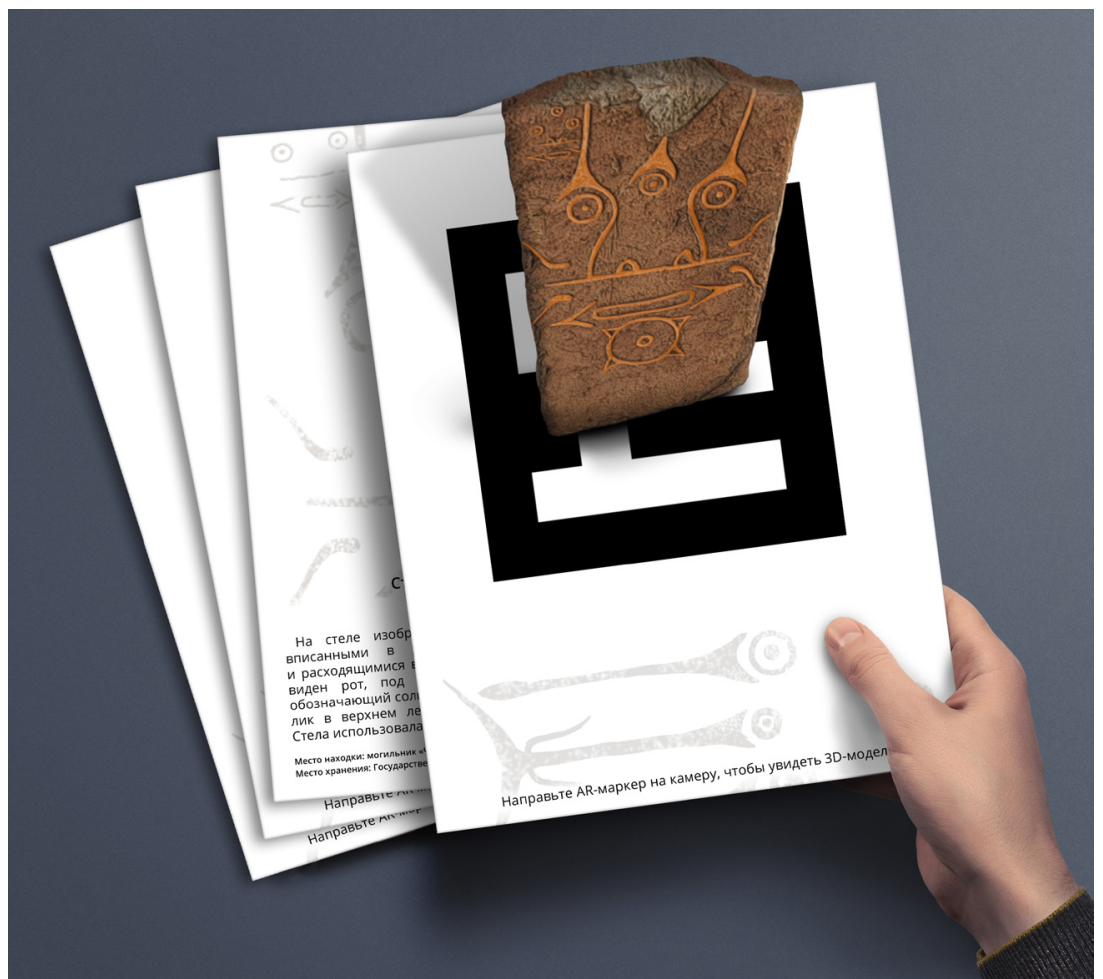

Project "Augmented Reality in the Open Storage of the Museum Depository of the State Hermitage Exemplified by the Stone Sculptures and Slabs of Okunev Culture"

cause steady interest among the audience that, sharing their impressions, attract new visitors to the museum. It is quite expensive to equip each exhibit with the static interactive complex. But, when downloading a special application, a visitor can get all the necessary information without a guide.

This technology has been used in the work of the students with V.I. Surikov Museum-Estate and the State Hermitage. For example, threedimensional visualization of the unique artifacts of Okunev Culture from the archaeological collection of the museum: monumental stone sculptures and slabs. Projects of presentations of archaeological collections with the use of the aforementioned technologies are a rather rare phenomenon. With the help of AR-code, swiped to the computer camera with the appropriate software, it is possible to see copies of archaeological artifacts recreated in threedimensional editor.

In the process of the museum's collection digitizing, a number of issues arose and their solutions were proposed in students graduation projects: "Development of the Methods for Museum Video Shooting: Technical and Scenic Aspects", "Augmented Reality in the Open Storage of the Museum Depository of the State Hermitage Exemplified by the Stone Sculptures and Slabs of Okunev Culture" and "DesignLayout for the Website of the Virtual Museum of Russian Archeology".

The latter was introduced at the 2nd International Conference "Virtual Archaeology" 2015, held in Saint Petersburg.

Experience in the use of information technologies accumulated by museums is convincing and effective. The appropriateness 
of their use in the museum is no longer a topic for discussion. It is necessary to develop guidelines for implementing digital strategy in museum affairs that will contribute to improving communication with the museum exhibit in the form of implementation of the various scenarios of the museum visit and representing it in the virtual world. The museum resource to achieve this goal is often not enough. In such cases, as shown by the above experience, it is possible to involve students who have the skills in work with the monuments of historical and cultural heritage and knowledge in the field of digital technologies prospective for the museum. The format of work when a local objective is set and the result is obtained is considered as the most effective. Such projects can be implemented in the course of educational and practical training, writing course and graduation projects.

\title{
References
}

Litvintseva, A.Yu. [2013]. Dopolnennaia real'nost' kak instrument visualizatsii museinogo soderzhaniia [Augmented Reality as an Instrument for Museum Content Visualization].

Slozhenikina, M.V. [2013]. Vnedrenie technologii dopolnennoi real'nosti v kul'turnoobrazovatel'nuiu museinuiu sredu [Implementation of Augmented Reality Technology into Cultural and Educational Museum Environment], In Sborniki konferentsii NITs Sotsiosphera [SIC Social Sphere Conference Proceedings]. Vedecko vydavatelske centrum Sociosfera -CZ sro. (28).

Smirnova, T. [2010]. Virtual'nyi musei v sovremennom kul'turno-informatsionnom prostranstve [Virtual Museum in the Modern Cultural and Information Space]. Available at: http://www. posbook. ru/node/28. (102).

Borodkin, L.I., at al. [2011]. Vserossiiskii nauchno-metodicheskii seminar "Virtual'naia rekonstruktsiia istoriko-kul'turnogo naslediia v formatakh nauchnogo issledovaniia i obrazovatel'nogo protsessa" [All-Russian Scientific and Methodical Seminar "Virtual Reconstruction of Historic and Cultural Heritage in the Formats of Scientific Research and Educational Process"'].

Volodin, A.Yu. [2012]. Istoriia v tsifrovuiu epokhu: svoevremennye mysli [History in the Digital Era: Timely Thoughts], In Istoricheskaia Informatika [Historical Informatics]. (2).

http://www.nanonewsnet.ru/news/2010/gigapan-gigapiksely-na-sluzhbe-nauki

http://design-union.ru/portalnew/noosphera/technology/2287-2012-12-30-19-53-03

http://ieeexplore.ieee.org/xpl/articleDetails.jsp?arnumber=7419613\&searchWithin=\%22Authors \%22:.QT.N.\%20Pikov.QT.\&newsearch=true

\section{Технологии визуализации в музее (из опыта сотрудничества СФУ с музеями России)}

\author{
М.А. Лаптева, Н.О. Пиков \\ Сибирский федеральный университет \\ Россия, 660041, Красноярск, пр. Свободный, 79
}

Статья представляет опьт работы студентов Гуманитарного института Сибирского федерального университета с ведущими российскими музеями - Русским музеем и 
Государственным Эрмитажем. Демонстрируются результаты использования современных информационных технологий, делаюших посещение музеев интересным и результативным для зрителей, а музей современным актуальным сочиальным институтом, сохраняющим и представляющим культурное наследие в интерактивных контекстах.

Ключевые слова: музей, информационные технологии, фотосъемка, гигапанорамная съемка, сферическая панорама, интерактивность, дополненная реальность, виртуализация, Русский музей, Государственный Эрмитаж.

Научная специальность: 24.00.00 - культурология. 